\title{
Orbital Burkitt Lymphoma in an Immunocompetent Pediatric Patient
}

\author{
Estephania Feria-Anzaldo MD ${ }^{1}$, Grecia Yael Ortiz Ramirez $\mathrm{MD}^{1}$, Abraham Alejandro Medina \\ Andrade MD ${ }^{1}$, Clarisa E. Del Hierro Gutierrez MD ${ }^{1}$, Ariel Ceriotto García MD ${ }^{1}$, Luis Angel \\ Medina Andrade $\mathrm{MD}^{2} *$ \\ ${ }^{1}$ Oculoplastic Department, Association to Prevent Blindness in Mexico,Dr. Luis Sánchez Bulnes Hospital, \\ Vicente García Torres \# 46, San Lucas Coyoacán, 04030. Mexico City. \\ ${ }^{2}$ General Surgery Department, General Zone Hospital \#1A, Municipio Libre 1270, Portales Norte, 03300, \\ México City.
}

*Corresponding Author: Luis Angel Medina Andrade, General Surgery Department, General Zone Hospital \#1A, Municipio Libre 1270, Portales Norte, 03300, México City. Email: buismedina5@hotmail.com

\section{INTRODUCTION}

Burkitt lymphoma (BL) has been classified by the World Health Organization as a mature Bcell neoplasm, described in 1958 as a small, no cleaved B-cell,no-Hodgkin lymphoma, that was observed in African children in the endemic form, usually involving mandible, maxilla, orbit or adjacent orbital soft tissue structures like the eye $^{1-3}$. Other two forms of BL are the sporadic and the immunodeficiency-associated. The sporadic form occurs in non-endemic areas and typically begins with an abdominal tumor with bone marrow involvement, rarely with ocular or orbital involvement. The immunodeficiencyassociated form has been reported in association with HIV infection, SIDA and Epstein-Barr virus infection ${ }^{4-6}$.

\section{CASE REPORT}

A 5-year-old male patient is admitted with 2 weeks' history of rapid progressive proptosis of his left eye with inferior dystopia, also presents upper gaze and levoversion limitation, with vertical diplopia in all extraocular movements (Fig. 1). He denies trauma history, systemic symptoms, weight loss or lymphadenopathy. His best corrected visual acuity was 20/40 in right eye and 20/200 in left eye, with a normal examination of the right eye, baseline Hertel exophtalmometer reading was $15 \mathrm{~mm}$ on the right eye and $19 \mathrm{~mm}$ on the left eye.

The following tests were requested: blood count,CT-scan and A scan ultrasound biometry and B scan ocular ultrasound.
The blood count shows lymphocytosis $\left(9500 / \mathrm{mm}^{3}\right)$, monocytopenia $\left(53 / \mathrm{mm}^{3}\right)$ and neutropenia $\left(430 / \mathrm{mm}^{3}\right)$.

A $16.5 \mathrm{~mm}$ homogeneous ocupative lesion in the orbital roof was showed by B scans ocular ultrasound. The tumor caused indentation of the eye. With the A-scan ultrasound biometry, the tumor had low reflectivity, without flow. The CT-scan showed an isodense well-defined lesion in the orbital roof, with inferior displacement of the globe. There was no bone erosion (Fig. $2 \mathrm{~A}, 2 \mathrm{~B})$.

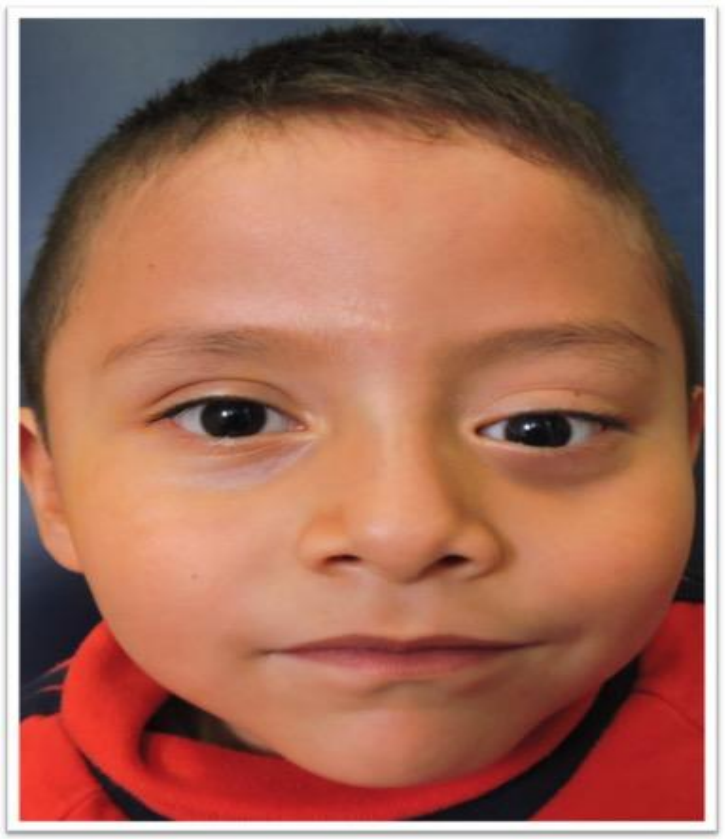

Fig.1. External appearance with proptosis of his left eye with inferior dystopia

An incisional biopsy was performed by a superior eyelid crease approach under general anesthesia. Pathology reported a dense 
lymphoid infiltrate disposed in a diffuse pattern, composed of medium size cells, with scarce cytoplasm. Multiple mitosis figures (16 in 10 high power fields), with apoptosis figures. A "starry sky" pattern was described, corresponding with an orbital Burkitt lymphoma (Fig.3). Epstein-Barr Ag test and ELISA for HIV were negative.
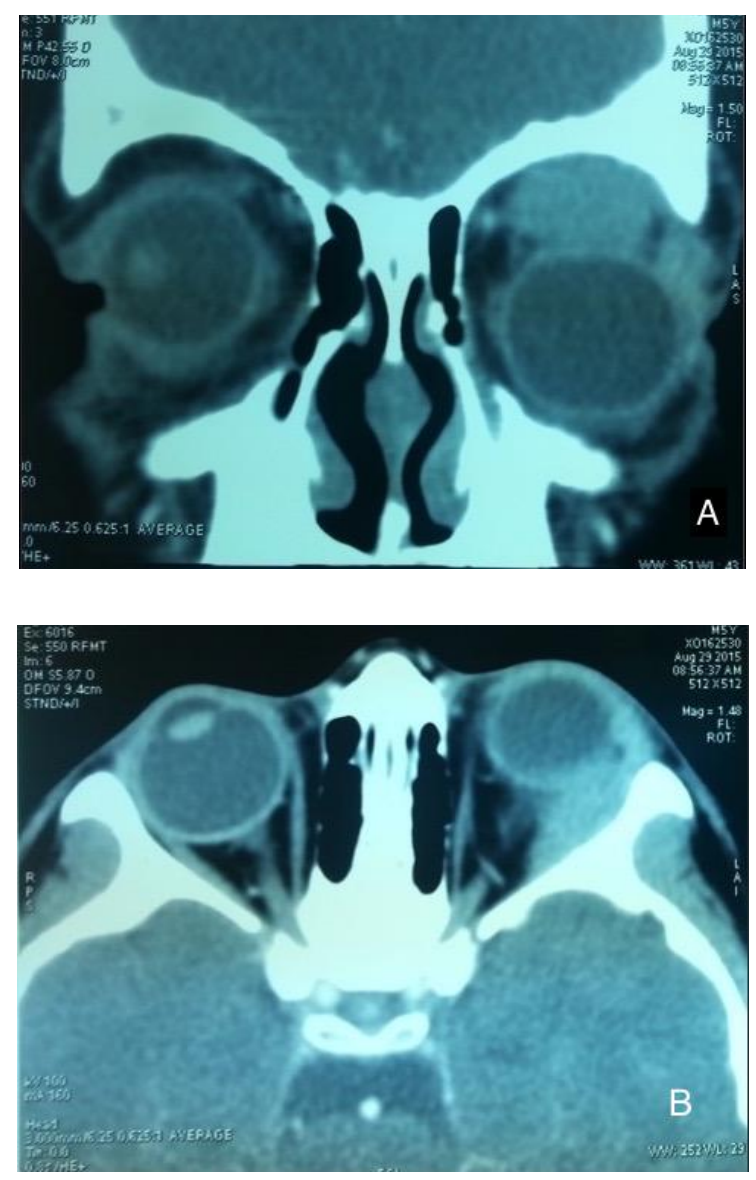

Fig2A, 2B. CT-scan-isodense well-defined lesion in the orbital roof, A Sagital projection, B Transversal projection

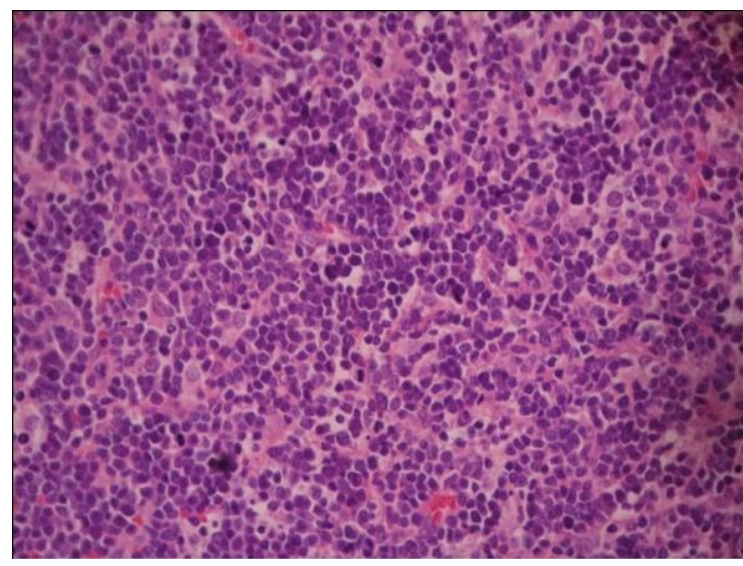

Fig.3. Dense lymphoid infiltrate disposed in a diffuse pattern composed of medium size cells, with scarce cytoplasm. Multiple mitosis figures (16 in 10 high power fields) with apoptosis images.

\section{DISCUSSION}

BL was initially described in the sub-Saharan Africa in pediatric population by the high incidence of jaw malignancy, and it was associated with Epstein-Barr infection. This tumor can arise from any location and the typically image observed in histologic exam is the "starry sky" pattern of lymphocytes ${ }^{7-9}$.

After some years a sporadic form was described in North American population. In contrast with the African tumors in jaw, maxilla and orbital bones, this sporadic form involving the abdomen, typically the ileocecal region, and rarely involving orbital or ocular structures ${ }^{10}$.

Originally the BL immunocompromised variant was described in patients with $\operatorname{AIDS}^{11-13}$. The infection by Epstein-Barr virus has been implicated in BL, being positive in $20 \%$ of sporadic cases, $40 \%$ in cases and as high as $95 \%$ in the endemic form ${ }^{9-11}$. One large study has reported that cases with positive Epstein-Barr antibody had better outcomes ${ }^{11-12}$.

$\mathrm{BL}$ is associated with c-myc translocation from chromosome 8 to 14 , and this was observed in $66 \%$ of patients with orbital BL in some series. In the literature is reported too that some cases present a translocation of the Ig light chain from chromosome 2 or 22 to the c-myc region in chromosome $8^{12-14}$.

Burkitt lymphoma has been described in people as old as 84 years, and this case was an immunocompetent woman which referred diplopia as main symptom, and was found to have a conjunctival mass including the parotid gland, lymph nodes and bone marrow ${ }^{13}$.

Levine et. al. conducted an 8-year review of 421 patients from the American Burkitt Cancer Registry, and reported a male to female ratio of 2.65:1 in patients younger than 13 years, and $1.35: 1$ in older than 13 years 18 .

Knowles and Jakobic in their review of 60 patients with orbital lymphoid neoplasm reported that the most common physical finding was a palpable mass in $90 \%$ of cases and proptosis is in $33 \%$, like the presented case ${ }^{15}$.

Central nervous system disease has been reported by Levine et al. as one of the most common sites for $\mathrm{BL}$, with $5 \%$ of involvement and therefore a high suspicious must be maintained when patients presents with orbital signs $^{18}$.

Some cases could present systemic spread in sporadic BL but in the presented case the patient didn`t have it. 
Immunophenotypically, all cytological variants express germinal center antigens BCL-6, CD 10, as well as superficial IgM. Also, you can find leucocyte antigens CD45, CD43, as well as B line antigens PAX5, CD79a, CD19, CD20, CD22 and plasmatic cell antigen CD38.

Prognosis remains guarded, with significant mortality within 1 year of presentation. Our patient was treated with systemic chemotherapy with the CODOX-M/IVAC regimen (cyclophosphamide, vincristine, doxorubicin, high-dose methotrexate / ifosfamide, etoposide, high-dose cytarabine), with remission after one year.

\section{Conclusions}

Sporadic orbital Burkitt lymphoma occurs in immunocompetent individuals with a wide age range. Almost $50 \%$ presents with an adjacent paranasal sinus involvement. Concurrent or eventual systemic involvement is common. Prognosis remains guarded, with significant mortality within 1 year of presentation. This is the first Orbital Burkitt Lymphoma in immunocompetent patient reported in Mexico.

\section{REFERENCES}

[1] Ferry J, Fung C, Zukerberg L, et al. Lymphoma of the ocular adnexa. A study of 353 cases. Am J Surg Pathol 2007; 31: 170-84.

[2] Coupland SE, Hummel M, Stein H. Ocular adnexal lymphomas: five case presentations and a review of literature. Surv Ophthalmol 2002; 47: 470-90.

[3] Isaacson $P$, Chott $A$, Nakamura $S$, et al. Extranodal marginal zone lymphoma of mucosa-associated lymphoid tissue (MALT lymphoma). In: Mature B cell neoplasms. WHO Classification of Tumours of Haematopoietic and Lymphoid Tissue. Lyon: IARC Press, 2008, p 214-217.

[4] Rainey JJ, Rochford R, Sumba PO, et al. Family environment is associated with endemic Burkitt lymphoma: a population based casecontrol study. Am J Trop Med Hyg. 2008; 78(2): 338-343.

[5] Link MP, Weinstein HJ. Malignant nonHodgkin lymphomas in chil- dren. En: Pizzo PA, Poplack DG, eds. Principles and practice of pediatric oncology, 5.a ed. 2006.
[6] Wysenbeek YS, Nissenkorn I, Cohen S, et al. Intraocular involve- ment of Burkitt's lymphoma in a Bedouin child. Pediatr Hematol Oncol 1987; 4:309-14.

[7] Kalina P, Black K, Woldenberg R. Burkitt's lymphoma of the skull base presenting as cavernous sinus syndrome in early childhood. Pediatr Radiol 1996; 26:416 -7.

[8] Donoso LA, Magargal LE, Eiferman RA. Meningealcarcinomato-sis secondary to malignant lymphoma (Burkitt's pattern). $J$ Pediatr Ophthalmol Strabismus 1981;18:48- 50.

[9] Sanchez Pina CS, Pascual-Castroviejo I, Fernandez VM, et al. Burkitt's lymphoma presenting as Tolosa-Hunt syndrome. Pediatr Neurol 1993; 9:157- 8.

[10] Ziegler JL, Andersson M, Klein G, Henle W. Detection of Epstein- Barr virus DNA in American Burkitt's lymphoma. Int $J$ Cancer 1976; 17:701-6. 35.

[11] Davi F, Delecluse HJ, Guiet P, et al. Burkittlike lymphomas in AIDS patients: characterization within a series of 103 human immunodeficiency virus-associated nonHodgkin's lymphomas. Burkitt's lymphoma study group. J Clin Oncol 1998; 16:3788-95.

[12] De-The' G , Geser A, Day NE, et al. Epidemiological evidence for a causal relationship between Epstein-Barr virus and Burkitt's lym- phoma from Ugandan prospective study. Nature 1978;274:756-61.

[13] Coupland SE, Hummel M, Stein H. Ocular adnexal lymphomas: five case presentations and a review of the literature. Surv Ophthalmol 2002;47:470 -90.

[14] Bouffet E, Frappaz D, Pinkerton R, Favrot M, Philip. Burkitt's lymphoma: a model for clinical oncology. Eur J Cancer 1991;27: 504-9.

[15] Knowles DM II, Jakobiec FA. Orbital lymphoid neoplasm: a clinicopathologic study of 60 patients. Cancer 1980;46:576 - 89.

[16] Knowles DM II, Jakobiec FA. Orbital lymphoid neoplasm: a clinicopathologic study of 60 patients. Cancer 1980;46:576 - 89.

[17] Banks PM, Arseneau JC, Graalnick HR. America Burkitt's lym- phoma: a clinicopathologic study of 30 cases. II. Pathologic cor- relations. Am J Med 1975; 58:322-9.

[18] Levine PH, Kamaraju LS, Connelly RR, et al. The American Burkitt's Lymphoma Registry: eight years' experience. Cancer 1982;49:1016-22.

Citation: Estephania Feria-Anzaldo et al. Orbital Burkitt Lymphoma in an Immunocompetent Pediatric Patient. ARC Journal of Surgery.2017; 3(2):1-3. doi:dx.doi.org/10.20431/2455-572X.0302001.

Copyright: (1) 2017 Authors. This is an open-access article distributed under the terms of the Creative Commons Attribution License, which permits unrestricted use, distribution, and reproduction in any medium, provided the original author and source are credited. 